\title{
TLR8 agonist VTX-2337 enhances NKG2D-mediated cytotoxicity of NK cells
}

\author{
Hailing Lu*, Yi Yang ${ }^{1}$, Veronika Groh², Thomas Spies ${ }^{2}$, Gregory Dietsch ${ }^{3}$, Maura Matthews ${ }^{3}$, Mary L Disis ${ }^{1}$, \\ Robert Hershberg ${ }^{3}$
}

From Society for Immunotherapy of Cancer 28th Annual Meeting

National Harbor, MD, USA. 8-10 November 2013

NK cells express an array of activating and inhibitory receptors, which facilitate the recognition and lysis of virally infected and transformed cells, but safeguard healthy cells from attack. NKG2D is an activating receptor expressed on the surface of NK cells that recognizes the ligands MICA/B and ULBP in human, which can be expressed on tumor cells or virus-infected cells. While NKG2D-mediated NK cell cytotoxicity plays an important role in tumor immune surveillance, cancer patients have been reported to have decreased expression and reduced function of the NKG2D receptor. We hypothesize that VTX-2337, a selective TLR8 agonist that activates myeloid DC and stimulates the production of proinflammatory cytokines including IL-12 and IL-18, may enhance NK cell function through NKG2D. PBMC from 11 donors were stimulated plate-bound anti-NKG2D antibody (clone 1D11), with or without prior incubation with VTX-2337 (500 nM, $24 \mathrm{hr}$ ). VTX-2337 significantly enhanced NKG2D-stimulated IFN- $\gamma$ production and CD107a expression, as assessed by FACS. To further investigate the impact of TLR8 activation on NKG2Dmediated cytotoxicity, VTX-2337-treated PBMC were incubated with human lymphoblastoid cell line C1R transfected with the NKG2D ligand, MICA. Pre-activation of PBMCs with VTX-2337 enhanced the lysis of C1R-MICA cells. Collectively these data suggest that the TLR8 agonist VTX-2337 can enhance NK cell-mediated immune surveillance against cancer through NKG2D and the recognition of MICA.

\section{Authors' details}

'Department of Medicine, University of Washington, Seattle, WA, USA. ${ }^{2}$ Clinical Research Division, Fred Hutchinson Cancer Research Center, Seattle, WA, USA. ${ }^{3}$ VentiRx Pharmaceuticals, Seattle, WA, USA.

'Department of Medicine, University of Washington, Seattle, WA, USA Full list of author information is available at the end of the article
Published: 7 November 2013

doi:10.1186/2051-1426-1-S1-P44

Cite this article as: Lu et al.: TLR8 agonist VTX-2337 enhances

NKG2D-mediated cytotoxicity of NK cells. Journal for ImmunoTherapy of

Cancer 2013 1(Suppl 1):P44.
Submit your next manuscript to BioMed Central and take full advantage of:

- Convenient online submission

- Thorough peer review

- No space constraints or color figure charges

- Immediate publication on acceptance

- Inclusion in PubMed, CAS, Scopus and Google Scholar

- Research which is freely available for redistribution
() Biomed Central 